\title{
Clinical applicability of the terminological subset of palliative care for dignified dying*
}

\author{
Aplicabilidade clínica do subconjunto terminológico cuidados paliativos para \\ um morrer com dignidade \\ Aplicabilidad clínica del subconjunto terminológico cuidados paliativos para \\ un morir con dignidad
}

How to cite this article:

Trybus T, Victor LS, Silva RS, Carvalho DR, Cubas MR. Clinical applicability of the terminological subset of palliative care for dignified dying. Rev Esc Enferm USP. 2021;55:e20210126. https://doi.org/10.1590/1980-220X-REEUSP-2021-0126

\author{
D Thais Trybus ${ }^{1}$ \\ (iD) Larissa Sydor Victor ${ }^{2}$ \\ iD Rudval Souza da Silva ${ }^{3}$ \\ iD Deborah Ribeiro Carvalho ${ }^{1}$ \\ iD Marcia Regina Cubas ${ }^{1}$ \\ * Extracted from the dissertation "Validação clínica
do subconjunto terminológico CIPE ${ }^{\circledR}$ cuidados
paliativos para um morrer com dignidade", Pontifícia
Universidade Católica do Paraná, Programa de
Pós-graduação em Tecnologia em Saúde, 2021.
${ }^{1}$ Pontifícia Universidade Católica do Paraná,
Programa de Pós-graduação em Tecnologia
em Saúde, Curitiba, PR, Brazil.
${ }^{2}$ Hospital Erasto Gaertener, Departamento
de enfermagem, Curitiba, PR, Brazil.
${ }^{3}$ Universidade do Estado da Bahia, Mestrado
Profissional em Saúde Coletiva, Salvador, BA, Brazil.
}

\begin{abstract}
Objective: To evaluate the clinical applicability of the terminological subset of the international classification for the nursing practice of palliative care for a dignified dying, in oncology. Method: Prospective study evaluating the clinical applicability of 33 nursing diagnoses/outcomes and 220 nursing interventions. It used case studies of 20 cancer patients undergoing palliation. The nursing process steps were operated by two nurses. Descriptive statistics was used to present, according to the theoretical model, the nursing diagnoses/ outcomes and interventions identified in the patients. All statements identified in patients at some point during care were considered applicable in clinical practice. Results: Twenty-nine nursing diagnoses/outcomes and 197 nursing interventions from the subset were identified. Conclusion: In the context of palliative care in patients with cancer, the clinical applicability of $87.8 \%$ of the diagnoses/outcomes and $89.5 \%$ of the interventions that make up the palliative care terminological subset for dignified dying is affirmed.
\end{abstract}

\section{DESCRIPTORS}

Palliative Care; Standardized Nursing Terminology; Nursing Process. 


\section{INTRODUCTION}

Palliative care aims to provide quality of life and symptom control for people whose disease threatens the continuity of life. This care shall be provided to the patients and their family members by an interdisciplinary team, involving the physical, psychological, social, and spiritual aspects, for the prevention and relief of suffering ${ }^{(1)}$.

Nursing professionals, as team members, shall record the elements of their care practice - nursing diagnoses, outcomes and interventions, in line with palliative care and its theoreticalconceptual assumptions, bringing the knowledge related to the profession closer to that of the specialty. Nursing care shall be comprehensive, to support the patients and their family members' needs ${ }^{(2)}$, providing dignity in the process of dying and death.

In this regard, the use of standardized terminology, directed to the specific clientele and based on theoretical references, allows the provision of quality nursing care that provides dignity to patients in the process of dying and death ${ }^{(3)}$.

The subsets of the International Classification for Nursing Practice $\left(\mathrm{ICNP}^{\circledR}\right)$ are considered care technologies that offer nursing diagnoses (ND), outcomes (NO), and interventions (NI) that support nurses in the planning and standardized documentation of nursing care $^{(4)}$. The International Council of Nurses considers a priority the terminological subsets in the area of palliative care, a specialty in which the ICNP catalog of palliative care for a dignified death ${ }^{(5)}$ was published $^{\circledR}$. To give amplitude to the statements in the catalog, the $\mathrm{ICNP}^{\circledR}$ terminological subset of palliative care for dignified dying was developed in Brazil. Both were developed based on the model of care for the preservation of dignity ${ }^{(6)}$, which includes the categories: concerns related to the disease; dignity conservation repertoire; and social dignity inventory, which represent the physical, emotional, spiritual, and social aspects influencing dignity.

To affirm the pertinence and relevance for clinical practice, the subsets need to undergo concept, content and clinical validation processes ${ }^{(7)}$, which are inserted in different stages of the construction of subsets: analysis of terms, cross mapping, analysis of statements in isolation and final analysis of the subset ${ }^{(8)}$.

It appears that subset validation studies are limited to concept and content validation, with clinical applicability studies not being identified in the literature through case studies ${ }^{(7)}$. In its turn, the Brazilian method does not describe the clinical validation step; however, the authors indicate that this gap shall be overcome by research analyzing the clinical applicability of the subset through case studies operationalized by the steps of the nursing process and based on the theoretical model adopted for the elaboration of the subset ${ }^{(8)}$.

This aspect was also identified in a recent integrative review on the subject, in which the authors argue that, despite the evolution of research regarding the construction of subsets in Brazil and worldwide, the clinical validation of subsets through clinical case studies is still a gap in knowledge ${ }^{(7)}$.

Understanding that the clinical validation step is essential to consolidate the use of $\mathrm{ICNP}^{\circledR}$ by clinical nurses, to bring the knowledge produced in the academy closer to clinical practice $^{(7,8)}$, the present study contributes in an innovative way to fill the gap related to clinical validation in the area of palliative care in oncology.

Thus, this article presents a contribution to the Brazilian method $^{(8)}$, with the operationalization of the clinical applicability of terminological subsets, thus bringing an advancement to the development of the proposal for clinical validation. It aims to assess the clinical applicability of the ICNP terminological subset ${ }^{\circledR}$ of palliative care for dignified dying in oncology.

\section{METHOD}

\section{TyPe OF Study}

Prospective study for assessment of care technology clinical applicability, which used case studies operationalized by the steps of the nursing process. The terminological subset ICNP ${ }^{\circledR}$ of palliative care for dignified dying was used as an empirical basis, consisting of $33 \mathrm{ND} / \mathrm{NO}$ and $220 \mathrm{NI}$, organized according to the model of care for the preservation of dignity ${ }^{(9)}$.

\section{Population and Sample Definition}

The universe of participants consisted in $100 \%$ of patients with cancer diagnosis, hospitalized in the palliative care unit or under monitoring by the palliative team during the collection period, their companions, and the seven nurses from the services. Patients and companions were randomly selected from the list available at the services. After applying the inclusion criteria, 20 patients (14 from the Hospital and six from the Hospice) participated in the study; 18 companions (two patients were unaccompanied), and two nurses. It should be noted that nurses were characterized as participants, considering the recommendations of the Research Ethics Committee.

\section{Local and Period of Collection}

The study was carried out in two complementary services, of the same sponsoring institution, in the city of Curitiba, Paraná, Brazil. The first, a Hospital with 241 beds, characterized as a high complexity care center in oncology, a reference in the state, and the second, a Hospice with 26 beds, an exclusive unit for the care of patients in palliative care. The follow-up of patients took place from April to July 2020.

\section{Selection Criteria}

Patients of both sexes, aged over 18 years, with different oncological diagnoses were included, as well as the companions who participated in the care and were aware of the patient's history, symptoms, and complaints. The companions were selected through the question "do you know the patient's history, complaints, and symptoms?”. Nurses who were specialists in oncology and/or palliative care and who had clinical care experience of at least five years in the field of oncology were included. There was no exclusion criterion.

\section{Data Collection}

The data collection instrument was elaborated according to the steps of the nursing process, especially the nursing history and the determination of the ND/NO/NI. 
The instrument for collection of the nursing history was elaborated according to theory for the preservation of dignity ${ }^{(6)}$, containing: age, sex, marital status, religion, education, anamnesis data, physical examination, and observations. A pilot test was carried out, after approval by the ethics committee, to verify the adequacy of the instrument, and the participating patient was not included in the study. In parallel, a form containing a list with the patient's code, name, and medical record number was used, to ensure continuity of collection. This form was destroyed at the end of data collection. Characterization data of companions were not collected.

To compose the case studies, patients were evaluated according to the stages of the nursing process, with a maximum of five assessments being carried out per day, during the day, from Monday to Friday. Due to the Covid-19 pandemic, personal protection equipment was used and measures for hand and exclusive collection instruments sanitization were intensified.

Before data collection, the instrument, the ND/NO and NI described in the subset, and the operational definitions of the ND/NO were introduced to the nurses. Doubts about their application to operationalize the nursing process were solved.

The protocol established that the first collection would be performed within 24 hours after admission, and reassessments daily, until the patient's discharge or death. When the patient had a clinical condition that hindered communication, questions related to the anamnesis were asked to the companion, except for emotional or sentimental issues.

The initial nursing history was collected by the main researcher, so as not to expose the patient to double investigation or generate discomfort. After collection, the protocol established the verification of the recorded data by a second researcher.

The ND/NOs were identified based on the clinical indicators described in the operational definitions of the ND/ NOs of the INCP terminology subset ${ }^{\circledR}$ of palliative care for dignified dying. The ND/NOs were listed, in isolation, by the main researcher and one of the participating nurses. In cases of divergence in establishing the ND/NO, decision was made through consensus.

The planning and implementation steps were carried out according to the NO expected for the ND, established by the subset, and the proposed NIs were passed on to the nursing team responsible for the patient, to ensure the implementation and continuity of care. It should be noted that, for $\mathrm{ICNP}^{\circledR}$, the NO is a ND modified in time or by an intervention; thus, in the subset, such statements are not listed separately.

When data resulting in ND/NO or NI were identified that were not included in the ICNP terminological subset ${ }^{\circledR}$ palliative care for dignified dying, the statement was constructed from the ICNP ${ }^{\circledR}$ 2019-2020, following the guidance of the standard ISO $18.104^{(10)}$ or selected in other subsets, unrelated to palliative care.

In the evaluation stage, a new anamnesis and physical examination were performed, focusing on the identified NDs. The assessment was performed by the main researcher and checked by the same participating nurse who established the ND/NO, to confirm the information. Differences between the main researcher and the participating nurse were decided by consensus. As it was understood that the nursing process is a continuous process of evaluation-decision, patients were evaluated daily from hospitalization until discharge or death, so the same patient had ND/NO and NI modified throughout the collection period.

\section{Data Analysis and Treatment}

The case studies were organized in text to support the analysis. ND, NO, and NI were listed in a Microsoft Office Excel spreadsheet ${ }^{\circledR}$, being organized according to the category, theme and sub-themes of the theory used in the ICNP terminological subset ${ }^{\circledR}$ of palliative care for dignified dying. Data related to $\mathrm{ND} / \mathrm{NO}$ were analyzed using simple descriptive statistics, with absolute and relative frequency. Data related to NI were presented together according to the category of the theoretical model, due to the number of statements, and discussed by frequency.

For this research, the ND/NO and NI identified in patients, described in the case studies and present in the terminological subset, were considered applicable in clinical practice. In the absence of comparative research performing clinical applicability through case studies ${ }^{(11)}$, a numerical cut-off of frequency was not considered, understanding that the presence of ND/NO and NI, at least once, at some point in the provision of care, justifies the clinical applicability of the subset statement for patients with cancer in palliative care.

\section{Ethical Aspects}

This research is in accordance with Resolution 466/2012, of the National Health Council. The project was approved by the Research Ethics Committee of the Liga Paranaense de Combate ao Câncer, under Opinion No. 3.987.100/2020. Data collection was carried out after the acceptance of the participants, and signing of the Free and Informed Consent Term.

\section{RESULTS}

The 20 patients had a mean hospital stay of nine days (standard deviation $(\mathrm{SD})=10.5$ ), with a minimum of two days and a maximum of 50 days. The outcome in eight patients was hospital discharge and in 12, death. With regard to characterization, 11 patients were female and nine were male, and the mean age was 61 years $(s d=14.92)$, minimum age of 32 years and maximum of 89 years. As for education, seven patients had completed elementary school, six had some elementary school, three had finished high school, three had higher education, and one was illiterate. As for marital status, seven were married, five divorced, three single, four widowed, and one in a common-law marriage.

Thirty-nine different ND/NO were identified, in a total of $215 \mathrm{ND} / \mathrm{NO}$ identified at different times of the application of the nursing process, with an average of $11 \mathrm{ND}$ per case study (SD = 4.02) and minimum of five and maximum of 19 . All ND/NO identified by the participating nurses were in the ICNP terminological subset ${ }^{\circledR}$ of palliative care for dignified dying. The main researcher identified the need to include $10 \mathrm{ND} / \mathrm{NO}$ that were not included, seven of which from an unpublished academic work that validated ND/NO/NI for the surgical clinic of a university hospital in northeastern Brazil; one 
of the "terminological subset of the ICNP ${ }^{\circledR}$ for the self-care of the person with intestinal elimination ostomy" ${ }^{(12)}$; and two of free elaboration.

There was initial disagreement in establishing $69 \%$ of the $\mathrm{ND} / \mathrm{NO}$ and, in the consensus, $9 \%$ of the ND/NO identified by one of the two diagnosticians were excluded.

Table 1 shows the ND/NO for the category "concerns related to the disease", Table 2 for the "dignity conservation repertoire", and Table 3 for the "social dignity inventory".

Table 1 - Absolute and relative frequency of nursing diagnoses and outcomes in the category "disease-related concerns" in the evaluated patients $(\mathrm{N}=20)$. Curitiba, PR, Brazil, 2020.

\begin{tabular}{lcc}
\hline Nursing diagnosis and outcome & Patients (n) & $\%$ \\
\hline Independence level & & \\
Cognitive acuity & 12 & 60 \\
Communication, impaired & 12 & 60 \\
Orientation, impaired & 1 & 5 \\
Orientation, improved & & 30 \\
Functional capacity & 6 &
\end{tabular}

\begin{tabular}{|c|c|c|}
\hline \multicolumn{3}{|l|}{ Symptoms of suffering } \\
\hline \multicolumn{3}{|l|}{ Physical suffering } \\
\hline Discomfort & 8 & 40 \\
\hline Dyspnea & 5 & 25 \\
\hline Pain & 9 & 45 \\
\hline Edema & 7 & 35 \\
\hline Fatigue & 5 & 25 \\
\hline Wound & 8 & 40 \\
\hline Hypoxia & 1 & 5 \\
\hline Nausea & 5 & 25 \\
\hline Breathing, impaired & 11 & 55 \\
\hline Risk of cachexia & 11 & 55 \\
\hline Sleep, impaired & 5 & 25 \\
\hline Intravenous access, preserved* & 13 & 65 \\
\hline Constipation* & 12 & 60 \\
\hline Urinary elimination, impaired ${ }^{+}$ & 4 & 20 \\
\hline Skin hydration, decreased* & 2 & 10 \\
\hline Peristomal skin integrity, preserved $^{\ddagger}$ & 3 & 15 \\
\hline Risk of pressure injury* & 6 & 30 \\
\hline Bleeding risk* & 1 & 5 \\
\hline Somnolence* & 2 & 10 \\
\hline Vomiting $^{+}$ & 3 & 15 \\
\hline \multicolumn{3}{|l|}{ Psychological suffering } \\
\hline Distress related to death & 4 & 20 \\
\hline Emotional status, impaired & 7 & 35 \\
\hline Chronic sadness & 3 & 15 \\
\hline Fear* & 1 & 5 \\
\hline
\end{tabular}

* Unpublished academic work that validated nursing diagnoses, outcomes, and interventions for the surgical clinic of a university hospital in northeastern Brazil; ${ }^{+}$Free elaboration; ${ }^{\ddagger}$ "ICNP Terminological Subset ${ }^{\circledR}$ for the self-care of the person with intestinal elimination ostomy"(12).
Table 2 - Absolute and relative frequency of nursing diagnoses and outcomes of the "dignity conservation repertoire" in the patients evaluated $(\mathrm{N}=20)$. Curitiba, PR, Brazil, 2020.

\begin{tabular}{|c|c|c|}
\hline Nursing diagnosis and outcome & Patients (n) & $\%$ \\
\hline \multicolumn{3}{|l|}{ Perspectives for the conservation of dignity } \\
\hline \multicolumn{3}{|l|}{ Continuity of self } \\
\hline Dignity, preserved & 9 & 45 \\
\hline \multicolumn{3}{|l|}{ Hope } \\
\hline Expectation of hope & 4 & 20 \\
\hline Hopelessness & 2 & 10 \\
\hline \multicolumn{3}{|l|}{ Autonomy/control } \\
\hline Risk of interruption of self-care & 5 & 25 \\
\hline \multicolumn{3}{|l|}{ Acceptance } \\
\hline Adherence to the therapeutic regime & 9 & 45 \\
\hline $\begin{array}{l}\text { Attitude of facing the process of dying and } \\
\text { death, impaired }\end{array}$ & 6 & 30 \\
\hline \multicolumn{3}{|l|}{ Practices of conservation of dignity } \\
\hline \multicolumn{3}{|l|}{ Live "the moment" } \\
\hline Will to live & 4 & 20 \\
\hline \multicolumn{3}{|l|}{ Search for spiritual comfort } \\
\hline Risk of spiritual distress & 1 & 5 \\
\hline
\end{tabular}

Table 3 - Absolute and relative frequency of nursing diagnoses and outcomes in the category "inventory of social dignity" in the evaluated patients $(\mathrm{N}=20)$. Curitiba, PR, Brazil, 2020.

\begin{tabular}{lcc}
\hline Nursing diagnosis and outcome & Patients (n) & $\%$ \\
\hline Social support & 1 & 5 \\
$\quad$ Lack of family support & & \\
Level of care & 1 & 5 \\
$\quad$ Patient/caregiver relationship, impaired & & \\
Consequence concerns & 10 & 50 \\
$\quad$ Decision making process, impaired &
\end{tabular}

The ND "Spiritual Distress", "Despair", "Hypertension”, and "Hypothermia", contained in the subset, were not identified in any case study; thus, there was no applicability in the context of palliative care in oncology.

A total of 197 (89.5\%) of the NIs that were included in the subset and $34 \mathrm{NIs}$ that were not included were implemented. Of the subset NIs, one NI related to the diagnosis "Hypoxia" was not prescribed for any patient and 22 NI were not used because they were related to the non-applied ND. The most frequent NIs $(n=13)$ were "Obtain data on response to guidance", "Provide guidance to reality" and "Inform the patient about people, time and place, as necessary", all referring to the ND "Orientation, Impaired". Table 4 shows the distribution of NI identified according to the theory categories for the preservation of dignity.

Some interventions were used less frequently, even in ND that had a higher frequency of appearance. The NI referring to guidelines for the family were not applied to patients who were not accompanied by family members during the hospitalization 
Table 4 - Total number of nursing interventions identified in patients followed in the case studies and the percentage in relation to the total number of interventions in the subset, according to the categories of the theory for the preservation of dignity. Curitiba, PR, Brazil, 2020.

\begin{tabular}{lcc}
\hline Category & $\begin{array}{c}\text { Nursing } \\
\text { interventions } \\
\text { identified }\end{array}$ & $\begin{array}{c}\% \text { in relation to the total } \\
\text { number of nursing interventions } \\
\text { in the category }\end{array}$ \\
\hline $\begin{array}{l}\text { Concerns with the } \\
\text { disease }\end{array}$ & 125 & $86.8 \%$ \\
$\begin{array}{l}\text { Dignity conservation } \\
\text { repertoire }\end{array}$ & 54 & $93.1 \%$ \\
$\begin{array}{l}\text { Social dignity } \\
\text { inventory }\end{array}$ & 18 & $100 \%$ \\
\hline
\end{tabular}

period. The NI "Help people to eat, according to their needs and acceptance" and "Investigate chewing and/or swallowing problems" were applied only to patients with the capacity to eat and understand the orientation.

\section{DISCUSSION}

Patients in palliative care have intense symptoms that are difficult to control, and hospitalization is an option to provide comfort ${ }^{(13)}$. The very similar distribution among female patients and those with a hospital stay of more than seven days, including hospitalizations of more than one month, was also identified in a study that described the clinical and sociodemographic profile of patients hospitalized in palliative care ${ }^{(14)}$, which reflects the assertiveness of the selection of participants in this research.

Patients who demand greater complexity of care remain hospitalized for longer and have a higher percentage of death ${ }^{(15)}$ and those in palliative cancer care have advanced diseases ${ }^{(14)}$, justifying the higher death outcome in those included in this research.

The identification of human responses in the person undergoing cancer palliative care is complex, which requires a multidimensional and comprehensive approach ${ }^{(16)}$. Subjectivity arising from the human condition, manifested from some symptoms, and the presence of a large number of ND/NO, can generate difficulties in the care plan for patients in the final stage of life, even when the nurse has sharp clinical reasoning ${ }^{(16)}$. This aspect was identified in the results presented, when analyzing the data on the number of ND/NO identified per patient. This set of diagnoses can lead nurses to conclude their choice for the diagnosis of terminal syndrome ${ }^{(17)}$, which is not part of the ICNP terminological subset ${ }^{\circledR}$ of palliative care for dignified dying.

The use of a terminological subset promotes the incorporation of the ICNP ${ }^{\circledR}$ to the nurse's work process and directs the elaboration of the $\mathrm{ND} / \mathrm{NO} / \mathrm{NI}^{(4)}$, which was verified in this research when the nurse used the ND/NO of the subset, demonstrating that this technology supports the reasoning for the nursing process.

In the category "concerns related to the disease", the frequency of the ND "Communication, Impaired", can be explained by the difficulty of communication in terminality. A study that evaluated the difficulty of communication indicated its presence in $55.3 \%$ of patients ${ }^{(18)}$. When it comes to impaired verbal communication, strategies such as calm speech, pauses, and time for uninterrupted response and active listening are used $^{(19)}$. In the present research, these strategies were shown to be limited during the active process of death.

The ND "Orientation, Impaired" was identified more clearly in the patients evaluated. This situation is explained by the fact that issues related to changes in orientation, such as delirium, for example, were observed in $70 \%$ of patients in palliative care, being more prevalent in the period before death ${ }^{(20)}$.

Breathing undergoes changes in the final stage of life, due to the increase in respiratory distress in the last weeks of life, which can reach severe levels ${ }^{(21)}$, corroborating the prevalence of the ND/NO "Breathing, Impaired". The worsening of respiratory symptoms was evidenced in the results, being identified in patients who progressed to death.

Also in the category "concerns related to the disease", the application of the ND "Risk of Cachexia" was evidenced. Cachexia and the difficulty of eating can lead to suffering of cancer patients family members, since food has an important cultural role ${ }^{(22)}$.

Palliative care seeks life with dignity to provide a dignified death, with respect for the individual's beliefs and values ${ }^{(23)}$. Despite the frequency of the ND/NO "Dignity, Preserved", it should, in principle, be applied to all patients; however, the difficulty of communication hindered the assessment of characteristics for its definition.

As for the frequency of the ND/NO "Adherence to the Therapeutic Regimen", it is clear that adherence to the proposed therapies is multifactorial, that is, it is related to several factors that influence the way the individuals will change their behavior to follow what was proposed. When it comes to patients in palliative care with oncological diagnoses, there are few studies on the subject, being directed towards adherence to pain treatment ${ }^{(24)}$. Thus, this ND shall be the object of other studies to improve its identification accuracy.

In the category "social dignity inventory", the ND/NO "Decision Making Process, Impaired" was more evidently present in patients whose outcome was death. It is assumed that issues related to loss in the decision process are related to the presence of the ND/NO "Communication, Impaired", as communication is a necessary instrument for the patient to express their wishes. This way, an advance directive of will can be elaborated together with the patient, while he/she still has the autonomy to decide what he/she would like to be done or not, preserving his/her will even at the time of the dying process ${ }^{(25)}$.

Some justifications for the complementarity of ND/NO that were not included in the subset are highlighted. The first concerns the importance of incorporating ND/NO and NI into the peripheral catheter. In a Brazilian study, $87.1 \%$ of terminal cancer patients used the device ${ }^{(17)}$. The second, in relation to the ND/NO "Constipation", is that it is a frequent clinical finding in cancer patients who use opioids, affecting $60 \%$ to $90 \%$ of them ${ }^{(26)}$.

When using ND/NO from other subsets, the nurse shall analyze the applicability of some NI carefully. An example can be given for the NI "Stimulate the consumption of fiber-rich 
foods and adequate water intake", from the ND "Constipation”, which was not applied to all patients due to feeding difficulties.

Regarding the ND that were not identified in the evaluated patients, a study that developed and validated the ICNP terminological subset ${ }^{\circledR}$ for patients in palliative care with malignant tumor wounds also did not validate the ND "Spiritual Anguish"(27). Despite the importance of approaching the spiritual dimension, there is a lack in the training of health professionals regarding the spiritual aspects of care ${ }^{(28)}$, which makes this approach difficult. Thus, limitations to identify, analyze, and address spirituality are present, even among professionals trained in palliative care ${ }^{(27)}$.

The ND "Despair" is related to the relationship with what constitutes human existence ${ }^{(29)}$. The condition of profound hopelessness, devaluation, emptiness and discouragement, according to the operational definitions of the empirical basis of this research, was not identified in the patients followed, which may be related to the biopsychosocial support provided by the team of the institution where the data were collected, which based on the principles of palliative care.

In their turn, the NDs "Hypertension" and "Hypothermia" are linked to vital signs that are routinely checked and recorded. The fact that these NDs have not been used may be related to the pattern in vital signs found in patients in the final stage of life, whose blood pressure tends to decrease, and temperature, to increase ${ }^{(30)}$. Thus, although they are not applied in this research, such ND/NOs and respective NIs can be used in other contexts.

\section{Study Limitations and Contributions}

The fact that the participating nurses have clinical experience and specialization in the area of oncology and palliative care contributed to a better assessment of the patients included; however, not establishing the expertise criterion for the use of nursing terminology can be considered a weakness for identifying new statements.

The study design is innovative and, as a contribution to the area of nursing in palliative care, the results favor the performance of the nursing process based on standardized terminology in oncology. Another contribution is related to the description of methodological steps for the analysis of clinical applicability, to support the proposal for clinical validation of ICNP terminological subsets ${ }^{\circledR}$, through case studies.

\section{CONCLUSION}

The clinical applicability of $29 \mathrm{ND} / \mathrm{NOs}(87.8 \%)$ and 197 NIs $(89.5 \%)$ of the ICNP ${ }^{\circledR}$ terminological subset of paliative care for dignified dying is affirmed in cancer patients undergoing palliative care. For this context, the ND/NOs "Spiritual Anguish", "Despair", "Hypertension" and "Hypothermia" and their NIs were not applied, which does not preclude its use in other areas of palliative care. There was a limit to the approach of psychospiritual needs in patients with "Communication, Impaired". Consequently, interventions in this scope were also not applied.

The use of case studies, based on the steps of the nursing process, allowed to analyze the clinical applicability of the ICNP terminological subset ${ }^{\circledR}$ of palliative care for dignified dying in clinical practice.

We suggest, as future studies, the assessment of the clinical applicability of ICNP terminological subsets ${ }^{\circledR}$ in other contexts, to consolidate a strategy for the clinical validation of this technology.

\section{RESUMO}

Objetivo: Avaliar a aplicabilidade clínica do subconjunto terminológico da classificação internacional para a prática de enfermagem cuidados paliativos para um morrer com dignidade, em oncologia. Método: Estudo prospectivo, de avaliação de aplicabilidade clínica de 33 diagnósticos/ resultados e 220 intervenções de enfermagem. Usou estudos de caso de 20 pacientes oncológicos em paliação. As etapas do processo de enfermagem foram operacionalizadas por duas enfermeiras. Utilizou-se estatística descritiva para apresentar, conforme o modelo teórico, os diagnósticos/resultados e intervenções de enfermagem identificados nos pacientes. Foram considerados aplicáveis na prática clínica todos os enunciados identificados nos pacientes em algum momento da assistência. Resultados: Foram identificados 29 diagnósticos/resultados de enfermagem e 197 intervenções de enfermagem do subconjunto. Conclusão: No contexto dos cuidados paliativos em pacientes com doença oncológica afirma-se a aplicabilidade clínica de $87,8 \%$ dos diagnósticos/resultados e 89,5\% das intervenções que compõem o subconjunto terminológico cuidados paliativos para um morrer com dignidade.

\section{DESCRITORES}

Cuidados Paliativos; Terminologia Padronizada em Enfermagem; Processo de Enfermagem.

\section{RESUMEN}

Objetivo: Evaluar la aplicabilidad clínica del subconjunto terminológico de la CIPE para la práctica de enfermería cuidados paliativos para un morir con dignidad, en oncología. Método: Estudio prospectivo, para evaluar la aplicabilidad clínica de 33 diagnósticos/resultados y 220 intervenciones de enfermería. Fueron utilizados estudios de caso de 20 pacientes oncológicos sometidos a paliación. Las etapas del proceso de enfermería fueron operacionalizadas por dos enfermeras. Se utilizó la estadística descriptiva para presentar, de acuerdo con el modelo teórico, los diagnósticos/resultados e intervenciones de enfermería identificados en los pacientes. Fueron considerados aplicables en la práctica clínica todos los enunciados identificados en los pacientes en algún momento de la asistencia. Resultados: Se identificaron 29 diagnósticos/resultados de enfermería y 197 intervenciones de enfermería del subconjunto. Conclusión: En el contexto de los cuidados paliativos en pacientes con enfermedad oncológica se puede afirmar la aplicabilidad clínica de 87,8\% de los diagnósticos/resultados y 89,5\% de las intervenciones que componen el subconjunto terminológico cuidados paliativos para un morir con dignidad.

\section{DESCRIPTORES}

Cuidados Paliativos; Terminología Normalizada de Enfermería; Proceso de Enfermería. 


\section{REFERENCES}

1. World Health Organization. WHO palliative care [Internet]. Geneva: WHO; 2018 [cited 2019 Apr 16]. Available from: https://www.who.int/ news-room/fact-sheets/detail/palliative-care.

2. Hagan TL, Xu J, Lopez RP, Bressler T. Nursing's role in leading palliative care: A call to action. Nurse Educ Today. 2018;61:216-9. DOI: https:// doi.org/10.1016/j.nedt.2017.11.037.

3. Silva RS, Nóbrega MML, Medeiros ACT, Jesus NVA, Pereira A. Terms of the ICNP ${ }^{\circledR}$ used by the team of nurses assisting people in palliative care. Revista Eletrônica de Enfermagem 2015;17(2):269-77. DOI: https://doi.org/10.5216/ree.v17i2.27204.

4. International Council of Nurses. Guidelines for International Classification for Nursing Practice $\left(\right.$ ICNP $\left.{ }^{\circledR}\right)$ catalogue development [Internet]. Geneva: ICN; 2008. [cited 2021 Mar 02]. Available from: https://www.icn.ch/sites/default/files/inline-files/icnp_catalogue_development.pdf.

5. International Council of Nurses. Palliative Care for Dignified Dying [Internet]. Geneva: ICN; 2017. [cited 2021 Mar 06]. Available from: https:// www.icn.ch/sites/default/files/inline-files/Palliative_Care.pdf.

6. Chochinov HM. Dignity-conserving care - a new model for palliative care: helping the patient feel valued. JAMA. 2002;287(17):2253-60. DOI: https://doi.org/10.1001/jama.287.17.2253.

7. Querido DL, Christoffel MM, Nóbrega MML, Almeida VS, Andrade M, Esteves APVS. Terminological subsets of the International Classification for Nursing Practice: an integrative literature review. Rev Esc Enferm USP. 2019;53:e03522. DOI: http://dx.doi.org/10.1590/S1980$220 \times 2018030103522$.

8. Carvalho CMG, Cubas MR, Nóbrega MML. Brazilian method for the development terminological subsets of ICNP ${ }^{\circledR}$ : limits and potentialities. Rev Bras Enferm. 2017;70(2):449-54. DOI: http://dx.doi.org/10.1590/0034-7167-2016-0308.

9. Silva RS, Pereira A, Nóbrega MML, Mussi FC. Construction and validation of nursing diagnoses for people in palliative care. Rev Lat Am Enfermagem. 2017;25:e2914. DOI: https://doi.org/10.1590/1518-8345.1862.2914.

10. International Organization for Standardization. ISO 18104. Health Informatics integration of a reference terminology model for nursing. Genebra, ISO; 2003. p.1-28.

11. Strudwick G, Hardiker NR. Understanding the use of standardized nursing terminology and classification systems in published research: A case study using the International Classification for Nursing Practice ${ }^{\circledR}$. Int J Med Inform. 2016;94:215-21. DOI: https://doi.org/10.1016/j.ijmedinf.2016.06.012.

12. Carvalho CMG, Cubas MR, Nóbrega MML. Nursing diagnoses, outcomes and interventions in the care of people with intestinal elimination stoma. Brazilian Journal of Enterostomal Therapy - Revista Estima. 2018;16:e2218. DOI: https://doi.org/10.30886/estima.v16.518_PT.

13. Silva MAS, Diniz MA, Carvalho RT, Chiba T, Mattos-Pimenta CA. Palliative care consultation team: symptom relief in first 48 hours of hospitalization. Rev Bras Enferm. 2020;73(6):e20190391. DOI: https://doi.org/10.1590/0034-7167-2019-0391.

14. Oliveira AG, Ribeiro SZRS, Silva MIC, Vidal SA, Lopes LGF. Profile of hospitalizations in palliative care: a tool for management. Revista de enfermagem UFPE on line. 2018;12(8):2082-8. DOI: https://doi.org/10.5205/1981-8963-v12i8a235952p2082-2088-2018.

15. Santos CE, Klug D, Campos L, Losekann MV, Nunes TS, Cruz RP. Analysis of the Perroca Scale in Palliative Care Unit. Rev Esc Enferm USP. 2018;52:e03305. DOI: http://dx.doi.org/10.1590/s1980-220x2017037503305.

16. Passarelles DMA, Rios AA, Santana RF. Nursing diagnoses in oncology palliative care: integrative review. Enfermería global. 2019;18(3):579-611. DOI: http://dx.doi.org/10.6018/eglobal.18.3.345201.

17. Almeida AR, Santana RF, Amaral DM, Silva DES. https://doi.org/10.21675/2357-707X.2020.v11.n1.2460. Enfermagem em foco. 2020;11(1):50-6. DOI: https://doi.org/10.21675/2357-707X.2020.v11.n1.2460.

18. Barriguinha CIF, Mourão MTC, Martins JC. Communication and swallowing difficulties in palliative patients: patients, families and/or caregivers perspective. Audiology - communication research. 2017;22:e1655. DOI: https://doi.org/10.1590/2317-6431-2015-1655.

19. Vieira NFC, Santos MR, Puggina ACG. Prevalence of nursing diagnosis "impaired verbal communication" in the units of a private hospital. Enfermagem em foco. 2019;10(3):46-51. DOI: https://doi.org/10.21675/2357-707X.2019.v10.n3.2577.

20. García VD, Pérez ML, Reyna YZ. Prevalence of delirium using the Memorial Delirium Assessment Scale (MDAS) in advanced oncology patients admitted to a Palliative Care Unit. Risk factors, reversibility and treatment received. Medicina paliativa. 2018;25(4):245-54. DOI: https://doi. org/10.1016/j.medipa.2017.05.002.

21. Campbell ML, Kiernan JM, Strnadmark J, Yarandi HN. Trajectory of dyspnea and respiratory distress among patients in the last month of life. J Palliat Med. 2018;21(2):194-9. DOI: https://doi.org/10.1089/jpm.2017.0265.

22. Wheelwright S, Darlington AS, Hopkinson JB, Fitzsimmons D, Johnson C. A systematic review and thematic synthesis of quality of life in the informal carers of cancer patients with cachexia. Palliat Med. 2016;30(2):149-60. DOI: https://doi.org/10.1177/0269216315588743.

23. Zurriaráin RG. Palliative Care: An Ethical Solution Compatible with Human Dignity at the End of Life. Pers Bioet. 2019;23(2):180-93. DOI: http:// dx.doi.org/10.5294/pebi.2019.23.2.2.

24. Chou WC, Chen JS, Hung CY, Lu CH, Shao YY, Chiou TJ, et al. A nationwide survey of adherence to analgesic drugs among cancer patients in Taiwan: prevalence, determinants, and impact on quality of life. Support Care Cancer. 2019;27(8):2857-67. DOI: https://doi.org/10.1007/s00520018-4599-x.

25. Cervi TD. Palliative care and autonomy of the terminal patient: reflections on the vital testament in Brazil. Revista Videre. 2018;10(20):99-113. DOI: https://doi.org/10.30612/videre.v10i20.7709.

26. Larkin PJ, Cherny NI, La Carpia D, Guglielmo M, Ostgathe C, Scotté F, et al. Diagnosis, assessment and management of constipation in advanced cancer: ESMO Clinical Practice Guidelines. Ann Oncol. 2018;29(Suppl 4):iv111-25. DOI: https://doi.org/10.1093/annonc/mdy148.

27. Castro MCF, Fuly PSC, Garcia TR, Santos MLSC. ICNP ${ }^{\circledR}$ terminological subgroup for palliative care patients with malignant tumor wounds. Acta paulista de enfermagem. 2016;29(3):340-6. DOI: https://doi.org/10.1590/1982-0194201600047. 
28. Arrieira ICO, Thofehrn MB, Porto AR, Moura PMM, Martins CL, Jacondino MB. Spirituality in palliative care: experiences of an interdisciplinary team. Rev Esc Enferm USP. 2018;52:e03312. DOI: https://doi.org/10.1590/s1980-220x2017007403312.

29. Façanha LS, Sousa LS. Anguish and despair as a possibility of contructing human experience from the Sören Kierkegaard's philosophy. Conjectura: Filosofia e Educação. 2018;23(2):307-24. DOI: https://doi.org/10.18226/21784612.V23.N2.5.

30. Bruera S, Chisholm G, Santos R, Crovador C, Bruera E, Hui D. Variations in vital signs in the last days of life in patients with advanced cancer. J Pain Symptom Manage. 2014;48(4):510-7. DOI: https://doi.org/10.1016/j.jpainsymman.2013.10.019.

Financial support

Coordenação de Aperfeiçoamento de Pessoal de Nível Superior - Brasil (CAPES) - Código de Financiamento 001; Taxa Prosuc Conselho Nacional de Desenvolvimento Científico/CNPq (Bolsa Produtividade em Pesquisa - Processo n 305241/2018-4). 